\author{
ACTA MYCOLOGICA \\ Vol. 43 (1): 71-75 \\ 2008
}

\title{
New records of Erysiphales and Uredinales from Poland
}

\author{
AGATA WOLCZAŃSKA \\ Department of Botany and Mycology, Institute of Biology, Maria Curie-Skłodowska University \\ Akademicka 19, PL-20-033 Lublin, agata.wolczanska@poczta.umcs.lublin.pl
}

Wołczańska A.: New records of Erysiphales and Uredinales from Poland. Acta Mycol. 43 (1): 71-75, 2008.

Puccinia mei-mamillata Semad. wasfound for the first time in Poland on Angelica sylvestris L., Neoerysiphe galeopsidis (DC.) U. Braun on Melittis melisophyllum L. and Podosphaera xanthii (Castagne) U. Braun \& N. Shishkoff on Physalis alkekengi L. The new collections are described, illustrated and discussed herein. The key to the aecial state of rust fungi on Angelica in Poland is provided. Another four species are known from few localities on their hosts in Poland.

Key words: rust fungi, powdery mildews, distribution

\section{INTRODUCTION}

In the last few years there have been an increase in the number of reports on the occurrence of new species of fungi in Poland as well as on the extending range of native species and their invasion onto new hosts. This especially relates to powdery mildew (Erysiphales), but there are also data on Uredinales, Ustilaginomycetes and anamorphic fungi (e.g. Adamska 2001, 2005; Piątek 2003a,b, 2005; Piątek, Wołczańska 2004; Ruszkiewicz-Michalska 2006; Ruszkiewicz-Michalska, Michalski 2005; Wołczańska 2007; Wołczańska, Oklejewicz 2001; Wołczańska, Lamorski 2006; Wołczańska, Rozwałka 2005). This phenomenon may stem from natural migration of fungi or the introduction thereof into new areas, from migration of hosts and climatic changes, favorably enabling phytopathogens to develop fully. The present paper adds other plants to the list of hosts of phytopathogenic fungi in Poland and provides new data to their distribution. Detailed descriptions and illustrations are given for the species observed on new hosts: Puccinia mei-mamillata Semad. on Angelica sylvestris, Neoerysiphe galeopsidis (DC.) U. Braun on Melittis melisophyllum and Podosphaera xanthii (Castagne) U. Braun \& N. Shishkoff on Physalis alkekengi.

All the collected specimens have been deposited in the Mycological Herbarium of the Department of Botany and Mycology, University of Maria Curie-Skłodowska in Lublin (LBL M). The taxonomy and nomenclature of Uredinales are based on the 
monograph by Majewski $(1977,1979)$, and powdery mildews on the monograph and papers by Braun $(1987,1995,1999)$ and Braun \& Takamatsu (2000). The names of plants are taken after Mirek et al. (2002).

\section{LIST OF SPECIES}

\section{ERYSIPHALES}

Neoerysiphe galeopsidis (DC.) U. Braun [= Erysiphe galeopsidis DC.]

White, dense, persistent mycelium on the leaves. Appresoria lobed. Conidia ellipsoid-ovoid: 30-38(40) x 12-18 $\mu \mathrm{m}$, produced in chains (Fig. 1A, B).

SPECIMEN EXAMINED: on Melittis melisophyllum: Roztocze National Park, Maziarki reserve, 25.06.1998, LBL M-8650.

Remarks. This species was collected in Poland on 32 host plants. In Europe it was noted on Melittis melisophyllum in Austria, France, Switzerland and Montenegro (Braun 1995; Farr et al. [n.d.]).

Phyllactinia mali (Duby) U. Braun

Specimen EXAMINED: on Crataegus sp. (cult): Wyżyna Lubelska Upland, Lublin, road side, 5.11.2004, LBL M-8649.

Remarks. In Poland this species was recorded on this host in Opole and Pruszków (Sałata 1985).

Podosphaera xanthii (Castagne) U. Braun \& N. Shishkoff [= Sphaerotheca xanthii (Cast.) L. Junell]

White amphigenous mycelium on the leaves, appressoria indistinct, sometimes slightly nipple-shaped. Conidia ellipsoid-ovoid: $25-27.5$ x 15-17.5 $\mu \mathrm{m}$ produced in chains. The ascocarps grouped; they occurred on both sides of leaves and measured 87-115 (-125) $\mu \mathrm{m}$ in diameter. The appendages on the lower part of ascocarp; they were septate and brown - the longest ones were subhyaline at the end. In the chasmothecium one sessile ascus: 60-70 x 50-60 $\mu \mathrm{m}$. The oculus (apical thin-walled part of ascus) large, measured 15-20 $\mu \mathrm{m}$ in diameter (Fig. 2A). Ascospores broadly ellipsoid: 13,5-17,5 x 10-14 $\mu \mathrm{m}$.

SPECIMENS EXAMINED: on Physalis alkekengi: Western Carpathians, Pogórze Środkowobeskidzkie foothills, Rymanów, garden, cultivated, 9.09.2002, LBL M-8651; Wyżyna Lubelska Upland, Lublin, garden, cultivated, 19.09.2003, 21.09.2003, 22.10.2003, LBL M-10049-10051;

Remarks. Sphaerotheca fusca (Fr.) Blumer sensu Braun $(1987,1995)$ was divided into two species: Podosphaera xanthii (Castagne) U. Braun \& N. Shishkoff and Podosphaera fusca (Fr.) U. Braun \& N. Shishkoff due to the diameter of oculus and the size of ascomata (Braun, Takamatsu 2000). The Polish collections on Physalis alkekengi belong to Podosphaera xanthii - the oculi (thin, apical parts of asci) are large and measured 15-20 $\mu \mathrm{m}$ (Fig. 2A). For comparison was used specimen published by Wołczańska and Oklejewicz (2001) as Sphaerotheca fusca (Fr.) Blumer (=Podosphaera fusca (Fr.) U. Braun \& N. Shishkoff) on Doronicum austriacum Jacq., Beskid Niski Mts., Jasiel, 31.07.1991, LBL M-7126. The oculi of asci of this species measure 10-12 $\mu \mathrm{m}$ and are distinctly smaller than those of Podosphaera xanthii (Fig. 2B). 
In connection to the diagnosis proposed by Braun and Takamatsu (2000) other specimens reported as Sphaerotheca fusca sensu Braun $(1987,1995)$ require revision. In the mycological literature there is only little information about the occurrence of Podosphaera xanthii on Physalis spp. It was recorded under this name only in Taiwan (Cheng et al. 2006) and as Sphaerotheca xanthii from Bulgaria (Farr et al. [n.d.]).

\section{UREDINALES}

\section{Aecidium clematidis DC.}

Specimen exAmined: on Clematis sp. (cult.): Western Carpathians, Pogórze Środkowobeskidzkie foothills, Rymanów, garden, 24.06.2006, LBL M-8648.

REMARKs. In Poland this species was recorded only on Clematis recta in Kazimierz Dolny, Puławy (Majewski 1977) and in Kazimierski Landscape Park (RomaszewskaSałata et al. 1991-1992).

\section{Puccinia mei-mamillata Semad.}

Pycnia: hypogenous on leaves, scattered between aecia, diameter $80 \mathrm{um}$. Aecia: Aecidium - type, as longitudinal or roundish, orange groups up to $6 \mathrm{~mm}$, on leaf petioles and hypogenous on leaves along the nerves. The outer wall of peridium cells distinctly thicker [8-12 $\mu \mathrm{m}]$ than the inner wall [3-6(8) $\mu \mathrm{m}]$. Aeciospores angular globoid, $16 \times 20$ $\mu \mathrm{m}$, delicately verrucosus with distinct clots, spore wall hyaline 0.5-1 $\mu \mathrm{m}$ (Fig. $1 \mathrm{C}$ ).

SPecimen eXAmined: on Angelica sylvestris: Western Carpathians, Pogórze Środkowobeskidzkie foothills, Rymanów, meadow, 21.05.1992, LBL M-8584.

Remarks. Puccinia mei-mamillata is a heteroaecious species. So far in Poland aecia of this fungus have been collected only on Mutellina purpurea (Poir.) Thell. on Śnieżnik Mt (Sudety Mts) and on Babia Góra Mt (Beskid Żywiecki Mts) (Majewski 1979) and lately also in the Tatra Mountains (Wołczańska, Piątek 2008, mscr.). Urediniospores and teliospores occur on Polygonum bistorta L. in the south and in the middle part of Poland (Majewski 1979) and on Polygonum viviparum L. in the Tatra National Park (Beskid) (Sałata et al. 1984). On Angelica sylvestris this species has not been collected in Poland so far. It was recorded on this host in the Czech Republic, Lithuania, Norway, Germany, Russia and Sweden (Farr et al. [n.d.]).

In Poland aecia of the following agents of rust fungi can occur on Angelica species (Majewski 1979): Puccinia bistortae DC., Puccinia polygoni-vivipari Karst., Puccinia pimpinellae (Str.) Röhl. and Puccinia mei-mamillata. The aeciospores of Puccinia mei-mamillata are the smallest and have big, seceding clots. Important differences are also visible in the thickness of peridium cells. P. mei-mamillata has different proportion between the outer and inner peridium walls than Puccinia pimpinellae and the thickness of peridium cell walls of the other species is distinctly smaller (Tab.1).

Key to the aecial state of rust fungi on Angelica ssp. in Poland

1. Aeciospores with distinct, big, seceding clots ......................Puccinia mei-mamillata

$1^{*}$ Aeciospores without clots

2

2. The inner wall of peridium cells thicker than the outer wall ..Puccinia pimpinellae

$2^{*}$ The inner wall of peridium cells thiner than the outer wall .................................. 3

3. Aeciospores big, 20-32 x 14-21 $\mu \mathrm{m}$; the spore wall 2-3 $\mu \mathrm{m}$............Puccinia bistortae $3^{*}$ Aeciospores smaller, diameter 18-25 $\mu \mathrm{m}$; the spore wall 3-4 $\mu \mathrm{m}$ 
A. Wołczańska

Table 1

Comparison of aecia of rust fungi occurring on Angelica spp. in Poland

\begin{tabular}{|l|c|c|l|l|}
\hline \multirow{2}{*}{ Species } & \multicolumn{2}{|c|}{ Aeciospores } & \multicolumn{2}{c|}{ Peridium } \\
\cline { 2 - 5 } & \multicolumn{1}{|c|}{ dimensions } & $\begin{array}{c}\text { occurrence of } \\
\text { clots }\end{array}$ & outer cell & \multicolumn{1}{c|}{ inner cell } \\
\hline Puccinia bistortae* $^{*}$ & $20-32 \times 14-21 \mu \mathrm{m}$ & - & $3-3,5 \mu \mathrm{m}$ & $2-3 \mu \mathrm{m}$ \\
\hline $\begin{array}{l}\text { Puccinia polygoni- } \\
\text { vivipari* }\end{array}$ & $\emptyset 18-28 \mu \mathrm{m}$ & - & to $5 \mu \mathrm{m}$ & $\begin{array}{l}\text { thinner than the } \\
\text { outer wall }\end{array}$ \\
\hline $\begin{array}{l}\text { Puccinia } \\
\text { pimpinellae }\end{array}$ & $\emptyset 18-25 \mu \mathrm{m}$ & - & $4-5 \mu \mathrm{m}$ & $4-8 \mu \mathrm{m}$ \\
\hline $\begin{array}{l}\text { Puccinia mei- } \\
\text { mamillata }\end{array}$ & $\emptyset 16-20 \mu \mathrm{m}$ & + & $8-12 \mu \mathrm{m}$ & $3-6(-8) \mu \mathrm{m}$ \\
\hline
\end{tabular}

* data after Majewski (1979)

\section{Puccinia sessilis Schneid.}

Specimen examined: on Platanthera bifolia (L.) Rich.: Roztocze, Roztocze National Park, Maziarki reserve, beech forest, 25.06.1998, LBL M-8647.

Remarks. In Poland this species was recorded on this host only in Lipiny near Lubin (Majewski 1979).

\section{Uromyces ononidis Pass.}

Specimen eXAmined: on Ononis arvensis L.: Western Carpathians, Pogórze Środkowobeskidzkie foothills, Rymanów, waste land, 21.09.1994, LBL M-8646.

Remarks. In Poland this species was recorded on this host near Międzyrzec Podlaski (Majewski 1977) and in Rymanów (Wołczańska 1994).

\section{REFERENCES}

Adamska I. 2001. Microscopic fungus-like organisms and fungi of the Słowiński National Park (NW Poland). II. Acta Mycol. 36 (1): 31-65.

Adamska I. 2005. Fungal species new in Poland on Carex and Juncus. Acta Mycol. 40 (1): 19-24.

Braun U. 1987. A monograph of the Erysiphales (powdery mildews). Beihefte zur Nova Hedwigia 89, Berlin-Stuttgart.

Braun U. 1995. The powdery mildews (Erysiphales) of Europe. Gustav Fisher Verlag, Jena - StuttgartNew York.

Braun U. 1999. Some critical notes on the classification and generic concept of the Erysiphaceae. Schlechtendalia 3: 48-54.

Braun U., Takamatsu S. 2000. Phylogeny of Erysiphe, Microsphaera, Uncinula (Erysipheae) and Cystotheca, Podosphaera, Sphaerotheca (Cystotheceae) inferred from rDNA ITS sequences - some taxonomic consequences. Schlechtendalia 4: 1-33.

Cheng C. W., Chen R. S., Chang W. H., Tsay J. G. 2006. The occurrence of powdery mildew on Physalis angulata caused by Podosphaera xanthii. Plant Prot. Bull. 48: 41-51.

Farr D.F., Rossman A.Y., Palm M.E., McCray E.B. [n.d.]. Fungal Databases, Systematic Mycology and Microbiology Laboratory, ARS, USDA. Retrived June 10, 2008, from http://nt.ars-grin.gov/fungaldatabases/.

Majewski T. 1977. Flora Polska. Grzyby (Mycota) 9: Basidiomycetes, Uredinales. I. PWN, WarszawaKraków.

Majewski T. 1979. Flora Polska. Grzyby (Mycota) 11: Basidiomycetes, Uredinales. II. PWN, WarszawaKraków.

Mirek Z., Piękoś-Mirkowa H., Zając A., Zając M. 2002. Flowering plants and pteridophytes of Poland. A checklist. W. Szafer Institute of Botany, Polish Academy of Sciences, Kraków.

Piątek M. 2003 a. Erysiphe azaleae and Erysiphe syringae-japonicae introduced in Poland. Mycotaxon 87: $121-126$. 
Piątek M. 2003 b. Puccinia lagenophorae (Urediniomycetes), a neomycete new in Poland. Polish Bot. J. 48 (1): 83-85.

Piątek M. 2005. First report of powdery mildew of Ligustrum caused by Erysiphe syringae-japonicae. Pl. Pathol. 54: 578.

Piątek, M., Wołczańska A. 2004. Some phytopathogenic fungi rare or new to Poland. Polish Bot. J. 49 (1): 67-72.

Romaszewska-Sałata J., Sałata B., Mułenko W. 1991-1992. Wstępne uwagi o mikroskopowych grzybach fitopatogenicznych Kazimierskiego Parku Krajobrazowego. Folia Soc. Sci. Lubl. 32, Biol. (1/2): 31-39.

Ruszkiewicz-Michalska M. 2006. Mikroskopijne grzyby pasożytnicze w zbiorowiskach roślinnych Wyżyny Częstochowskiej. Monogr. Bot. 96: 1-140.

Ruszkiewicz-Michalska M., Michalski M. 2005. Puccinia scillae (Uredinales) fungus new for Poland. Acta Mycol. 40 (1): 63-70.

Sałata B. 1985. Flora Polska. Grzyby (Mycota) 15: Ascomycetes, Erysiphales. PWN, Warszawa-Kraków.

Sałata B., Romaszewska-Sałata J., Mułenko W. 1984. Notatki mikologiczne z Tatrzańskiego Parku Narodowego. Acta Mycol. 20 (1): 13-21.

Wołczańska A. 1994. New localities of some rare species of Uredinales in Poland. Acta Mycol. 29 (1): 95-98.

Wołczańska A. 2007. First report of Erysiphe carpinicola (perfect state) in Poland. Pl. Pathol. 56 (2): 354.

Wołczańska A., Lamorski T. 2006. Puccinia laserpitii (Uredinales), a new species for Poland. Polish Bot. J. 51 (2): 221-224.

Wołczańska A., Oklejewicz K. 2001. New and rare species of parasitic fungi in Poland. Acta Mycol. 36 (1): 7-12.

Wołczańska A., Piątek M. 2008. Some phytopathogenic fungi rare or new to Poland - second contribution (mscr.).

Wołczańska A., Rozwałka R. 2005. Urocystis muscaridis (Ustilaginomycetes), a fungal species new in Poland. Polish Bot. J. 50 (1): 93-96.

\section{Nowe informacje o grzybach fitopatogenicznych w Polsce}

\section{Streszczenie}

W pracy przedstawiono nowe stanowiska dla siedmiu gatunków grzybów fitopatogenicznych. Trzy z nich znaleziono na roślinach żywicielskich, na których nie były dotąd notowane w Polsce: Puccinia mei-mamillata (na Angelica sylvestris), Neoerysiphe galeopsidis (na Melittis melisophyllum) i Podosphaera xanthi (na Physalis alkekengi). Podano dla nich opisy i ilustracje, a dla grzybów rdzawnikowych tworzących ecja na przedstawicielach rodzaju Angelica przygotowano klucz do ich oznaczania. Pozostałe gatunki na podanych żywicielach znane są z niewielu stanowisk w Polsce. 

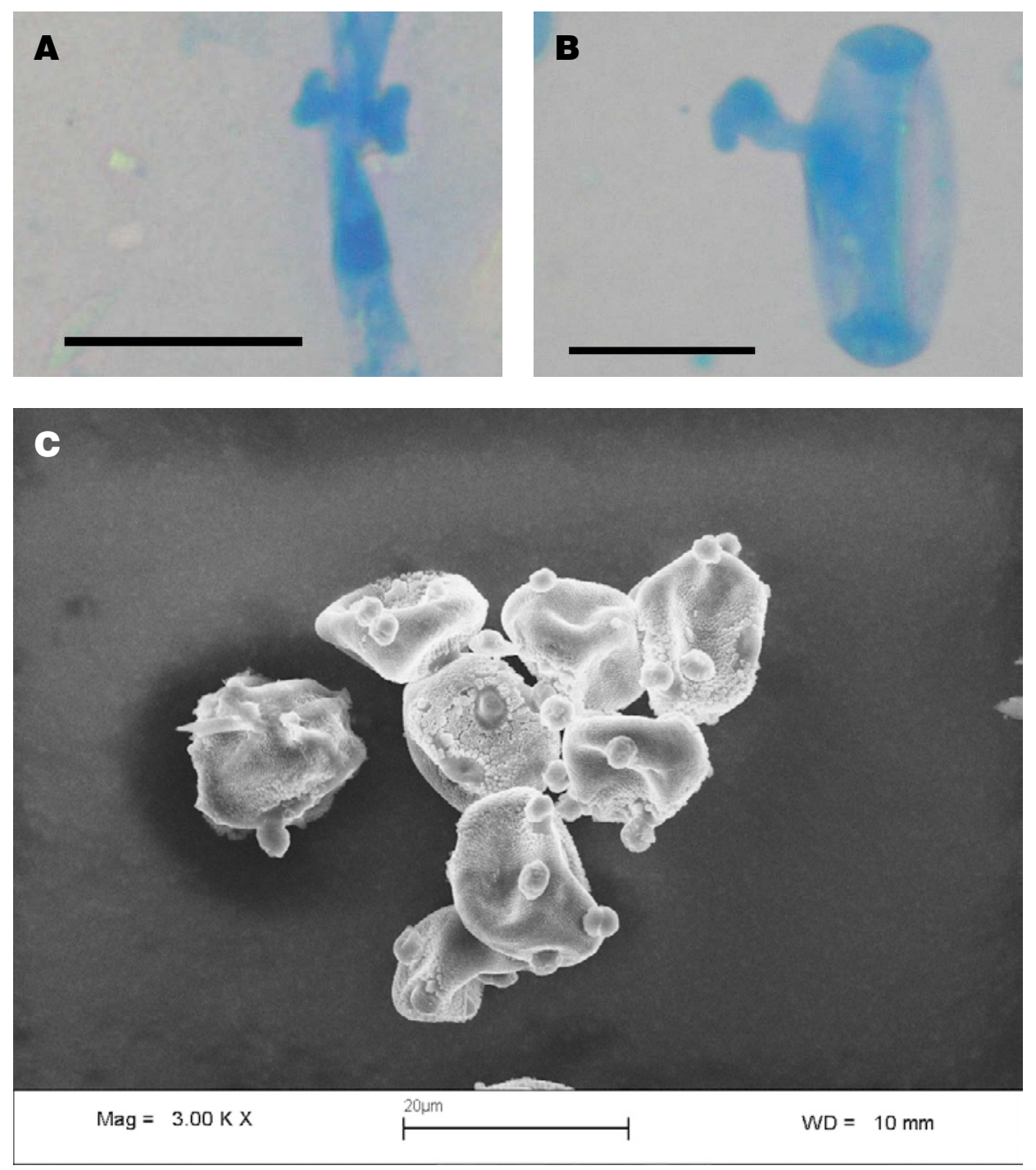

Fig. 1. A - lobed appressoria of Neoerysiphe galeopsidis; B - germinating conidium of Neoerysiphe galeopsidis; C - aeciospores of Puccinia mei-mamillata on Angelica sylvestris, scale bar $=20 \mu \mathrm{m}$. 

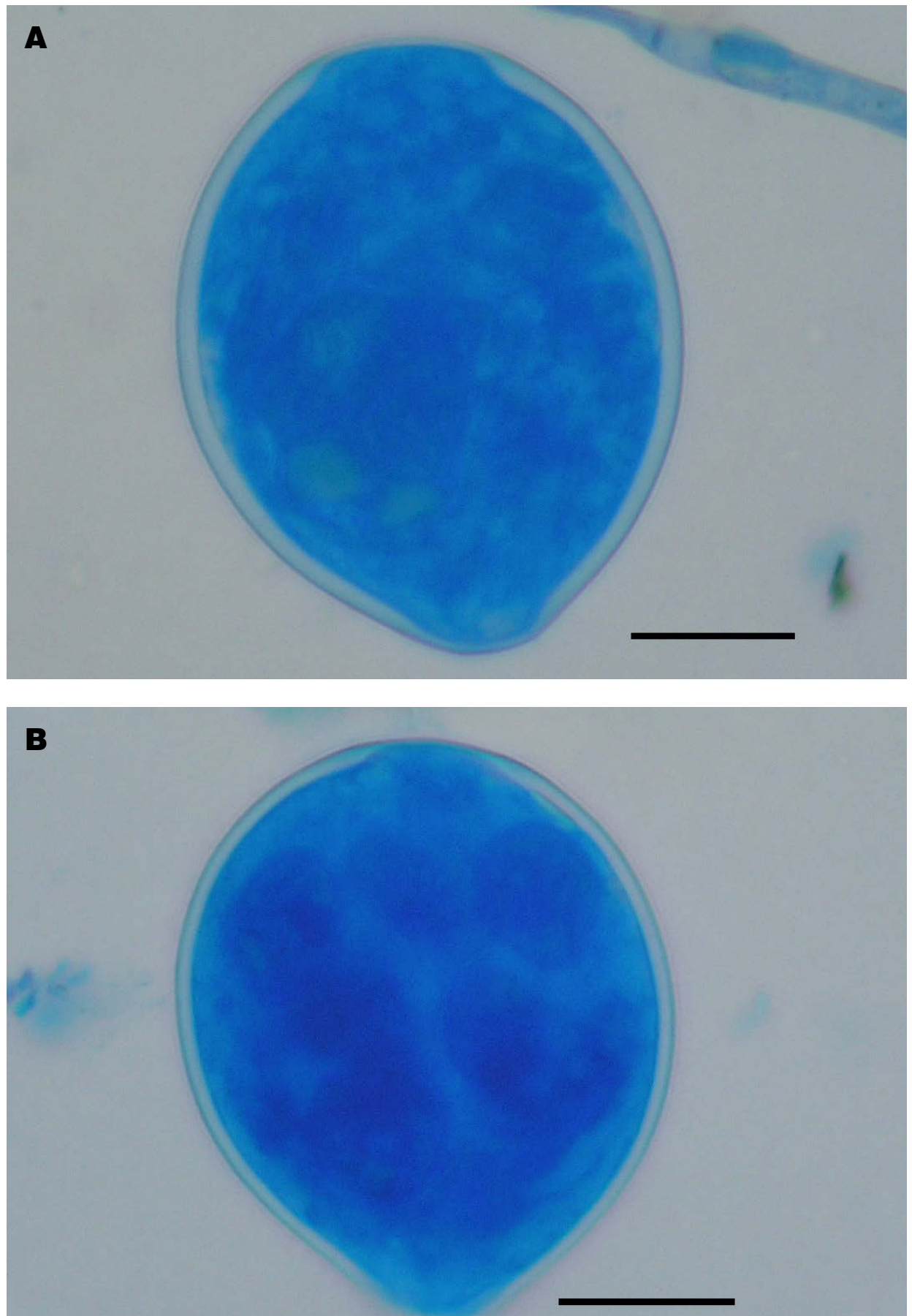

Fig. 2. A - ascus of Podosphaera xanthii; B - ascus of Podosphaera fusca, scale bar $=20 \mu \mathrm{m}$. 